\title{
MOSENEKE V THE MASTER 20012 SA 18 (CC): RACIAL DISCRIMINATION LAWS AND THE INTERESTS OF JUSTICE*
}

Prof Christa Rautenbach ${ }^{* *}$

\section{BACKGROUND}

In 2002 the faculty of law of the Potchefstroom University for Christian Higher Education in collaboration with the Konrad-Adenauer-Stifttung embarked on a study on Politics, Socio-Economic Issues and Culture in Constitutional Adjudication. The project is aimed at analysing the influence of the Bill of Rights $^{1}$ in order to develop practical guidelines for South African courts confronted with issues of a political, socio-economic and cultural nature.

It is against this background that Moseneke $v$ The Master ${ }^{2}$ will be analysed. ${ }^{3}$ In this paper a general introduction of the facts of the case will be given. Thereafter the principles applied by die court in evaluating racial discrimination laws and the interests of justice will be highlighted. The case deals with certain provisions of the Black Administration Act, ${ }^{4}$ which applies to Africans living under a system of customary law, and emphasis will be on the development of practical guidelines for South African courts confronted with issues of a political, socio-economic and cultural nature. Finally, the relevant

* Paper delivered at the 5th Colloquium on Constitution and Law, Johannesburg 16 November 2002. The paper forms part of a project on Politics, Socio-Economic Issues and Culture in Constitutional Adjudication funded by the Konrad-Adenauer-Stiftung. Their financial assistance is hereby acknowledged with appreciation. Opinions expressed and conclusions drawn are those of the author and are not necessarily attributed to the Konrad-Adenauer-Stiftung.

** B lur LLB LLM LLD. Associate professor, faculty of law, Potchefstroom University for CHE.

1 Contained in chapter 2 of the Constitution of the Republic of South Africa 108 of 1996.

20022 SA 18 (CC).

3 The case illustrates the interaction between cultural and racial issues. It concerns laws which are applied to a certain group of people because of their race and not necessarily because of their culture.

438 of 1927. Hereinafter referred to as the Black Administration Act. 
changes proposed by the minister as a result of the decision reached in the Moseneke case will briefly be referred to.

\section{FACTS OF THE CASE ${ }^{5}$}

The facts of the case may be summarised as follows: ${ }^{6} \mathrm{Mr}$ Moseneke (hereinafter the deceased) died intestate in October 1999. He was survived by his wife and four sons (hereinafter the appellants). The deceased and the appellants led, what they called, an urban lifestyle. The estate of the deceased had to be administered by a magistrate, ${ }^{7}$ whilst all other estates must be administered by the master. ${ }^{8}$ The appellants were dissatisfied with the situation and expressed their concern to the master saying that the differential treatment amounted to unfair discrimination on the ground of race. Following on their letter to the master, the appellant referred the matter to the high court for an order declaring that regulation $3(1)^{9}$ is unconstitutional and that the master be instructed to administer the estate of the deceased. ${ }^{10}$ The high court made a final order, ${ }^{11}$ which declared regulation 3(1)

5 The provisions of the 1996 Constitution were applied to the case and, therefore, all references to the Constitution refer to the 1996 Constitution unless otherwise indicated.

6 Paras [2-4].

7 Regulation 3(1) of GN R2000 (Government Gazette 10601 of 6 February 1987). GN R2000 was promulgated under section 23(10) of the Black Administration Act. In terms of regulation 3(1) a magistrate must administer the estate of a deceased Black.

8 In terms of section 4 of the Administration of Estates Act 66 of 1965 the master has the power to administer all other estates. These estates will include the estates of whites, coloureds, Indian people and testate Black estates.

9 Regulation 3(1) reads: "All the property in any estate falling within the purview of paragraphs (a), (b), (c) and (d) of regulation 2 of these regulations [namely of a Black person leaving no valid will] shall be administered under the supervision of a magistrate in whose area of jurisdiction the deceased ordinarily resided and such magistrate shall give such directions in regard to the distribution thereof as shall seem to him fit...."

10 The draft order read as follows: "1. The provisions of clause $3(1)$ of the regulations promulgated in terms of the Black Administration Act 38 of 1927, as amended and published in Government Gazette 10601, Government Notice R200 of 6 February 1987, are declared invalid, unconstitutional and of no force and effect. 2. The respondent [appellant] is ordered to immediately register and oversee the administration and distribution of the estate of the late Sedise Samuel Moseneke [the deceased] in accordance with the provisions of the Administration of Estates Act 66 of 1965, as amended." See par [7].

11 The order reads: "1. The provisions of clause $3(1)$ of the regulations promulgated in terms of the Black Administration Act 38 of 1927, as amended and published in Government Gazette 10601, Government Notice R200 of 6 February 1987, are declared invalid, unconstitutional and of no force and effect. 2. The Respondent is ordered to immediately register and oversee the administration and distribution of the estate of the 
unconstitutional. The order was referred to the constitutional court for confirmation in terms of section $172(2)(a)^{12}$ of the Constitution. ${ }^{13}$

In the constitutional court, before Sachs J, it was pointed out that the invalidating of regulation 3(1) would create a lacuna. The striking down of regulation 3(1) deprived magistrates of the competence to administer intestate Black estates, whilst section $23(7)(a)^{14}$ of the Black Administration Act prohibits the master from administering intestate Black estates. The result would be that neither the master nor the magistrate would have the power to administer intestate Black estates. ${ }^{15}$ As a result of the lacuna the appellants requested, in the alternative, for an order declaring section 23(7)(a) of the Black Administration Act unconstitutional. ${ }^{16}$

The master opposed the application on grounds based on socio-economic considerations that included: ${ }^{17}$

(a) The lack of human resources, infrastructure, training and finance to administer the intestate estates of Blacks.

(b) The current workload of the masters of the high court which already provides substantial pressure and managerial problems.

late Sedise Samuel John Moseneke in accordance with the provisions of the Administration of Estates Act 66 of 1965, as amended."

12 Section 172(2)(a) reads: "The Supreme Court of Appeal, a High Court or a court of similar status may make an order concerning the constitutional validity of an Act of Parliament, a provincial Act or any conduct of the president, but an order of constitutional invalidity has no force unless it is confirmed by the Constitutional Court."

13 Constitution of the Republic of South Africa 108 of 1996 . Sachs J expressed doubt whether the relevant order necessarily required confirmation in terms of section 172(2)(a) of the Constitution, but nevertheless proceeded with the matter without deciding on the issue. See par [8].

14 Section 23(7) reads: "Letters of administration from the Master of the Supreme Court shall not be necessary in, nor shall the Master or any executor appointed by the Master have any powers in connection with, the administration and distribution of- (a) the estate of any Black who has died leaving no valid will; or (b) any portion of the estate of a deceased Black which falls under subsection (1) or (2).

15 Par [9].

16 The appellants argued, in chief, that the high court implicitly invalidated section 23(7). The minister argued that the constitutional court should not confirm the order given by the high court. If, however, the court were to confirm the relevant order, he argued that the declaration of invalidity should be suspended for a period of three years to enable the Parliament to revise the relevant legislation. In the alternative, the minister noted an appeal against the judgement of the high court. See Paras [11-12].

17 Par [14]. 
(c) The transferral of intestate Black estates from the magistrate's to the master's office would create chaos.

The minister advanced similar reasons and argued that: ${ }^{18}$

(a) It is logistically convenient to administer the estates of Black people by magistrates since magistrates are found in every small town;

(b) The methods of administration of deceased estates are informal and relatively swift;

(c) Magistrates have a better understanding of customary law; and

(d) It is cheaper to have the estates of Black people administered by magistrates since master's fees do not have to be paid.

The Women's Legal Centre Trust joined as amicus curiae and argued that both section 23(7)(a) and regulation 3(1) are unconstitutional, because they discriminate directly and indirectly against African women on the grounds of race, gender and culture. They supported the immediate invalidation of both section 23(7)(a) and regulation 3(1). According to them the administrative procedures under the Administration of Estates Act were far more protective of African women than those employed under the Black Administration Act. ${ }^{19}$

Sachs $\mathrm{J}$ then proceeded to consider the merits of the appellant's application as well as the merits of the appeal noted by the minister. In the following paragraphs the main issues emanating from the decision of Sachs $\mathrm{J}$ will be discussed in more detail.

18 In addition the minister referred to current developments in the field of customary law, namely the investigation of the SALC (project 90) and the Amendment of Customary Law of Succession Bill B109 of 1998, and argued that the administration of intestate Black estates should remain in the hands of the magistrate as an interim measure. See paras [15-16].

19 Par [17]. 


\section{MAIN ISSUES OF THE CASE}

\subsection{Invalidating racial discrimination laws}

According to Sachs $\mathrm{J}$ the laws differentiating between the administration of deceased estates of Blacks and other people is clearly rooted in "racist attitudes and practices of the past". He emphasises that all racial discrimination laws must change, but cautions against change "with a simple stroke of a pen." 20

The dangers associated with the mere striking down of racial discrimination laws are clearly illustrated by the judgement of the court a quo. The high court made an order declaring regulation 3(1) unconstitutional and invalid. The effect of the order was that magistrates had no competence to deal with intestate Black estates. At the same time, the master had no competence to deal with the same estates. The result was that intestate Black estates could not be administered at all. The president of the constitutional court detected this lacuna and required the parties to argue with regard to the validity of section $23(7)(a) .^{21}$

Although Sachs J's decision in the constitutional court rectified the lacuna caused by the striking down of regulation 3(1), without striking down section $23(7)(a)$, the order of the high court clearly illustrates that courts should not invalidate racial discrimination legislation without considering the implications of such an act.

Practical guideline: Racial discrimination laws should not be invalidated without considering all the implications of such an act.

\subsection{The interests of justice}

The principle of "interests of justice" figures very prominently I throughout the judgement of Sachs J. 
One of the issues was the absence of the minister in the high court proceedings. The question, which was dealt with by Sachs J, was whether the minister should be allowed to join the proceedings in the constitutional court if he was not a party in the high court. Sachs $\mathrm{J}$ pointed out that the minister should have been a party to the proceedings in the high court. ${ }^{22}$ The courts $^{23}$ have the power to regulate their own process taking into account the "interests of justice." ${ }^{24}$ Sachs $\mathrm{J}$ held that it would be in the interests of justice to permit the minister to join the proceedings in the constitutional court, because "there is a need to deal with this matter expeditiously." 25

The principle of interests of justice was also applied to solve the issue whether direct access should be granted to the appellants with regard to the constitutionality of section $23(7)(a) .{ }^{26}$ Rule $17(2)(a)$ of the constitutional court lay down that the application for direct access in terms of section 167(6)(a) of the Constitution must set out:

... the ground on which it is contended that it is in the interests of justice that an order for direct access be granted ... 27

Sachs held that it would be in the interests of justice to grant the appellants direct access by taking the following factors into consideration: ${ }^{28}$

22 In terms of rule 6(2) of the constitutional court (in Government Notice R757 in Regulation Gazette 6199 of 29 May 1998) the relevant authority responsible certain laws must be informed if the constitutionality of such laws are being disputed in a court. It was argued on behalf of the minister that the minister should have been a party to the proceedings in the high court because the proceedings in the high court concerned the validity of a regulation administered by his department. See par [13].

23 Constitutional court, supreme court of appeal and high courts.

24 Section 173 of the Constitution.

25 Par [13].

26 At this point it is important to remember that the order of the high court concerned only regulation 3(1) and, therefore, the appellants applied, in the alternative (in terms of rule 17 of the constitutional court), for direct access to the constitutional court for the invalidation of section 23(7).

27 Own ephasis.

28 Par [19]. It is clear that the court intermingled the principles "interests of justice" and "public interest" by saying: "...the public interest requires that the family [appellants] nevertheless be granted direct access to challenge the constitutionality of the section and the regulation". These principles are not the same and vary in various respects. It is clear that Sachs $\mathrm{J}$ meant that the interests of justice and not the public interest requires 
(a) The administrative deadlock, which affects the administration of deceased estates, must urgently be resolved;

(b) The discriminatory nature of section 23(7)(a) and regulation 3(1) necessitates extensive evidence to be led and evaluated in order for a decision on its constitutionality; and

(c) Both the minister and the master supported the matter being dealt with on the basis of direct access.

Practical guideline: Direct access to the constitutional court will be granted if it is in the interests of justice. The interests of justice depend on factors such as the urgency of the matter, the attitude of the parties concerned and the nature of the case before the court.

\subsection{The constitutionality of the Black Administration Act}

The Black Administration Act commenced on 1 September $1927^{29}$ with a view to the establishment of a national system for, amongst others, the recognition and application of customary law insofar as it was not repugnant to the western perception of public policy and natural justice. ${ }^{30}$

The aim of the Act is to "provide for the better management of Black Affairs."31 The term "Black" includes "any person who is a member of any aboriginal race or tribe of Africa." ${ }^{32}$ Sachs $\mathrm{J}$ explains: ${ }^{33}$

The Act systematised and enforced a colonial form of relationship and a subordinate black majority who were to have rights of citizenship and a subordinate black majority who were to be administered.

that the family be granted direct access. It is important to avoid the mixing of totally different principles.

29 With the exception of sections 22, 23 and 36 that commenced on 1 January 1929.

30 Olivier et al Inheemse Reg (Durban Butterworths 1998) 220; Van Niekerk "Indigenous Law in South Africa - a Historical and Comparative Perspective" 1990 Codicillus 39.

31 Preamble of the Act.

32 Section 35.

33 Par [20]. 
The classification of the category of persons that are subject to the provisions of the Act is solely based on a person's race. Within this context the Act equates race with culture. A dominant white male orientated government also based the Act on political considerations, such as the control of Black people by a dominant white minorty. Sachs $\mathrm{J}$ strongly condemned the Act and said: ${ }^{34}$

It is an affront to all of us that people are still treated as 'blacks' rather than as ordinary persons seeking to wind up a deceased estate, and it is in conflict with the establishment of a non-racial society where rights and duties are no longer determined by origin or skin colour.

For many years the Black Administration Act has been a bone of contention in discussions and the courts. Ngcobo $\mathrm{J}$ in Ex Parte Western Cape Provincial Government: In re DVB Behuising (Pty) Ltd $v$ North West Provincial Government ${ }^{35}$ described the act as part of

$\ldots$ an egregious apartheid law which anachronistically has survived our transition to a non-racial democracy. ${ }^{36}$

Sachs $\mathrm{J}$ echoed Ngcobo J's sentiments by saying the following:

It is painful that the Act still survives at all. The concepts on which it was based, the memories it evokes, the language it continues to employ, and the division it still enforces, are antithetical to the society envisaged by the Constitution. It is an affront to all of us that people are still treated as "blacks" rather than as ordinary persons seeking to wind up a deceased estate, and it is in conflict with the establishment of a non-racial society where rights and duties are no longer determined by origin or skin colour. ${ }^{37}$

In this case, however, the court had to decide whether a section 23(7)(a) of the Black Administration Act and regulation 3(1), promulgated in terms of this act, were constitutional or not. Section 23 regulates succession among

36 Par [1]. Also quoted by Sachs $\mathrm{J}$ in the Moseneke case at par [20].

37 Par [21]. 
persons living under customary law in South Africa. The African customary law of succession is in flux. For many years the law of intestate succession pertaining to Blacks in South Africa has been under discussion. Since the first South African Law Commission's (SALC) Report on the recognition of African customary marriages in 1986, the question as to what should happen to the African rules of intestate succession has been asked. ${ }^{38}$ The Recognition of Customary Marriages Act again brought this discussion to the fore. The SALC was under pressure to come up with new rules. In 1998 the SALC published Issue Paper 12 regarding the customary law of succession. ${ }^{39}$ In May 1998 the Department of Justice proposed the Amendment of Customary Law of Succession Bill and in August 2000 Discussion Paper 93 containing a Draft Bill for the Amendment of the Customary Law of Succession saw the light. ${ }^{40}$ However, up to date, no legislation has been promulgated in this regard.

Sachs $\mathrm{J}$ was asked to evaluate the constitutionality of section 23(7)(a) and regulation 3(1). He held that both provisions impose differentiation on the grounds of race, ethnic origin and colour and as such constitute unfair discrimination as envisaged in terms of the right to equality entrenched in

38 SALC Project 51 Report on Marriages and Customary Unions of Black Persons (1985) 83-91. Two Bills were recommend in the Report. The one lead to the promulgation of the Marriage and Matrimonial Property Law Amendment Act 3 of 1988. The other Bill dealt with customary marriages. The implementation of this Bill was suspended until the constitutional position of the so-called TBVC states and self-governing territories was clarified. In 1996 a new Project Committee was appointed and the issue of customary marriages was revived as Project 90. Various Discussion Documents have been issued since then. See, inter alia, SALC Project 90 Issue Paper 3 on Customary Marriages (1996) and SALC Project 90 Discussion Paper 74 on Customary Marriages (1997). The investigation finally led to the implementation of the Recognition of Customary Marriages Act 120 of 1998, which came into effect on 15 November 2000.

39 SALC Project 90 Issue Paper 12 on the Harmonisation of the Common Law and the Indigenous Law: Succession in Customary Law (1998).

40 B109 of 1998. The achievements of the Bill is the following (a) it promotes equality; (b) it excludes succession to traditional leadership from the workings of the Act and (c) it ensures that the right of the widow to a house of the deceased. For a discussion of the Draft Bill, see Rautenbach and Du Plessis "South African Law Commission's proposals for intestate customary law of succession: retrogression or progression?" De Jure ??. 
section $9(3)^{41}$ of the Constitution. The relevant provisions also constitute a limitation of the right to dignity entrenched in section 10 of the Constitution. ${ }^{42}$

Practical guideline: Legislation imposing differentiation on the grounds of race, ethnic origin and colour constitutes unfair discrimination as envisaged in terms of the right to equality.

\subsection{Limitation of rights}

The Constitution recognises the fact that fundamental rights are not absolute. Under section 36 fundamental rights may be limited in terms of "law of general application" to the extent that the limitation is "reasonable and justifiable" 43 in an open and democratic society based on certain values. ${ }^{44}$ In order to determine the reasonability and justifiability of the limitation, the following factors must be taken into account: ${ }^{45}$

(a) The nature of the right; ${ }^{46}$

(b) The importance of the purpose of the limitation; ${ }^{47}$

(c) The nature and extent of the limitation; ${ }^{4}$

(d) The relation between the limitation and its purpose; ${ }^{49}$ and

(e) Less restrictive means to achieve the purpose..$^{50}$

41 Section 9 deals with equality. It is generally accepted that equality refers to substantive equality in contrast to formal equality. See Rautenbach The Position of South African Women under the Law of Succession (2001 LLD thesis PU for CHE) 346 et al.

42 Par [22].

43 In S v Makwanyane 19956 BCLR 665 (CC) par [104] the court held that reasonability and justifiability will depend on the circumstances of each case.

44 These values include human dignity, equality and freedom. See section 36(1).

45 The factors are generally identical to the criteria that were formulated in Park-Ross $v$ Director: office for Serious Economic Offences 19951 SASV 539 (C) and $S v$ Makwanyane 19956 BCLR 665 (CC) par [104]. Although these cases dealt with the limitation clause in the 1993 Constitution it was confirmed in National Coalition for Gay and Lesbian Equality v The Minister of Justice 199812 BCLR 1517 (CC) par [34] that the principles applied in $S \vee$ Makwanyane will also apply in regard to section 36 of the 1996 Constitution.

46 Section 36(1)(a).

47 Section $36(1)(b)$.

48 Section 36(1)(c).

49 Section $36(1)(d)$.

50 Section 36(1)(e). 
In the Moseneke case the minister and the master suggested that the administration of intestate Black estates by magistrates were often convenient and inexpensive. The limitation on the administration of intestate Black estates was therefore reasonable and justifiable in terms of section 36 of the Constitution. ${ }^{51}$

Sachs $\mathrm{J}$ rejected their argument and held that the justification for the differentiation is "rooted in racial discrimination which severely assails the dignity of those concerned and undermines attempts to establish a fair and equitable system of public administration." ${ }^{52}$ Sachs $\mathrm{J}$ pointed out that convenience and cost should not be linked to race and that it should be at the disposal of all people of limited means that live in urban areas located far from the offices of the master. ${ }^{53}$ Sachs $\mathrm{J}$ held that section $23(7)(\mathrm{a})$ and regulation 3(1) were unreasonable and unjustifiable in an open and democratic society based on equality, freedom and dignity and, therefore, unconstitutional and invalid. He commented as follows:

I cannot accept that the provisions are reasonable and justifiable in an open and democratic society based on equality, freedom and dignity. No such society would tolerate differential treatment based solely on skin colour, particularly where the legislative provisions under consideration formed part of a larger package of racially discriminatory legislation which disadvantaged black people systematically and effectively. ${ }^{54}$

Sachs $\mathrm{J}$ held there could be no justification for the continuation of section 23(7)(a) and regulation 3(1) on the statute book. He pointed out that six years have passed since the start of constitutional democracy and only now persons whose dignity has been impaired have challenged these provisions. Nondiscriminatory provisions can easily accomplish the conveniences that section 23(7)(a) and regulation 3(1) might achieve. ${ }^{55}$

51 Par [22].

52 Section 195 of the Constitution. See par [22].

53 Par [22].

54 Par [23].

55 Par [23]. 
Practical guideline: Socio-economic factors such as convenience and low costs are insufficient limitations on fundamental rights if such factors are only rooted in racial discrimination.

\subsection{Just and equitable}

Sachs $\mathrm{J}$ was faced with a dilemma. He realised that invalidation of section 23(7)(a) and regulation 3(1) with immediate effect would create socioeconomic problems: He emphasised: ${ }^{56}$

To keep a manifestly racist law on the statute books is to maintain discrimination; to abolish it with immediate effect without making practical alternative arrangements is to provoke confusion and risk injustice.

In order to reach a just and equitable order he held as follows: ${ }^{57}$

(a) The status quo with regard to transactions already completed in terms of section 23(7)(a) and regulation 3(1) should be upheld.

(b) African families who die intestate and whose estates are not governed by the principles of customary law have a choice to have the estates administered by the master or the magistrate.

In order to reach the objective in (b), it was held that section 23(7)(a) was invalid with immediate effect, ${ }^{58}$ but the declaration of invalidity in respect of regulation 3(1) was suspended for a period of two years. In order to empower the master to administer deceased African estates, Sachs $\mathrm{J}$ held that the word "shall' in regulation 3(1) must be replaced with the word "may" for a period of two years. ${ }^{59}$

Quite unique to the judgement is the following order of Sachs $\mathrm{J}$ :

Any interested person may approach this Court for

56 Par [25].

57 Par [27].

58 That is 6 December 2000.

59 Par [27]. 
a variation of this order in the event of serious administrative or practical problems being experienced. ${ }^{60}$

In giving this order the court left the backdoor open for any future problems that could not be envisaged at the time of judgement. This order bears a remarkable resemblance to section 38 of the Constitution. ${ }^{61}$

Practical guideline: $A$ just and equitable order should entail the abolition of racial discrimination laws without provoking socio-economic problems.

\subsection{Gender equality}

As already stated, the Women's Legal Centre Trust argued that both section 23(7)(a) and regulation 3(1) are unconstitutional, because they discriminate directly and indirectly against African women on the grounds of race, gender and culture. ${ }^{62}$ Although they supported the court's invalidation of both section 23(7)(a) and regulation 3(1) they opposed the court's suspension of the invalidation order with regard to regulation 3(1) and argued that the court should make an order which would be operative as soon as possible. They contended that widows and children are being adversely affected by the way magistrates administer intestate Black estates and that regulation 3 was the "gateway into a system of administration which placed women and children of customary unions in an extremely vulnerable position." ${ }^{63}$ On the other hand, widows would participate in the appointment of executors if the Administration of Estates Act is applied and, therefore, it is desirable that the act applies to such estates.

Sachs $\mathrm{J}$ emphasised that the issue of gender equality is of major importance. He agreed that if

... the foundational value of creating a non-sexist

60 Par [31] at 5.

61 Section 38 reads: "Anyone listed in this section has the right to approach a competent court, alleging that a right in the Bill of Rights has been infringed or threatened, and the court may grant appropriate relief, including a declaration of rights. ..."

62 See par 1.

63 Par [29]. 
society is to be respected, proper consideration has to be given to the way the measures concerned impact in practice both on the dignity of widows and their ability to enjoy a rightful share of the family's worldly goods. ${ }^{64}$

Sachs $\mathrm{J}$ found, however, that there was not enough material before him in order to investigate complex issues regarding the intersection of race, gender, culture and class. This does not effect the right of any person to approach a competent court for suitable constitutional relief regarding the issues raised by the Women's Legal Centre Trust. ${ }^{65}$

\section{THE WAY FORWARD}

The Moseneke case deals with estates that devolve according to common law only and not with estates that devolve according to customary law. ${ }^{66}$ In case of the latter, section 23(7)(b) of the Black Administration Act prohibits the master from dealing with certain kinds of property accruing in terms of "Black law and custom" as described in section 23(1) and (2) of the Act. The order made by Sachs $\mathrm{J}$ also does not affect the other regulations issued under the Black Administration Act dealing with the powers and duties of magistrates to supervise such property.

The order of Sachs $\mathrm{J}$ was given on 6 December 2000. This means that regulation 3(1) will be invalid from 6 December 2002. The result will be that magistrates will no longer be able to administer intestate Black estates from that date. Up to date no substituting legislation have been promulgated.

The SALC has not finalised its investigation into the customary law of succession, and it is uncertain whether its recommendations in this regard will be available in time to meet the deadline of the constitutional court.

On 25 September 2002 the minister for justice and constitutional development introduced the Administration of Estates Amendment Bill ${ }^{67}$ into parliament.

67 B54 of 2002. The Bill are being dealt with in terms of section 75 of the Constitution. 
The Bill was referred to the Justice and Constitutional Development Portfolio Committee (JCDPC) who discussed the Bill on 23 October 2002. The JCDPC agreed upon a few amendments to the Bill and currently the Bill is upon for public submissions. ${ }^{68}$

The most important changes proposed by the Bill include, firstly, the administering of all estates, which do not devolve according to customary law, by the master. ${ }^{69}$ Secondly, the Bill makes provision for the designation of service points where officials of the Department of Justice and Constitutional Development will exercise functions on behalf of and under the direction of the master. ${ }^{70}$ The Bill is to come into operation on 5 December 2002, one day before the invalidation of regulation $3(1) .^{71}$

If the Bill comes into operation on 5 December 2003 there will be no more differentiation between the administration of white and black estates, which devolve according to the common law. However, the position regarding estates that devolve according to the customary law remains unchanged. These estates are administered under the control of magistrates without the interference of the master. The question remains whether it is plausible to have different systems of administration of estates at all. Should we not consider one system of administration of estates for all estates in South Africa? Or on the other hand, the question is whether benefits, such as low costs and convenience, should not be made available to everybody irrespective of their race, colour or ethnic origin?

68 B54-2002: Administration of Estates Amendment Bill [Found on Internet] http://www.pmg.org.za [Date of use 31 Oct 2002].

69 Clause 2 of the Bill.

70 Clause 1 of the Bill.

71 Clause 4 of the Bill. 